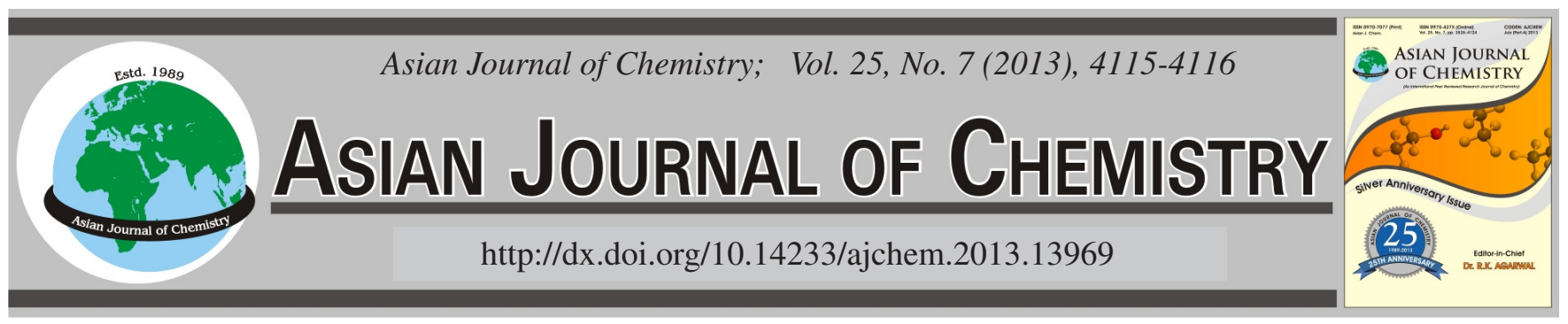

NOTE

\title{
Synthesis and Crystal Structure of 3,3'-Dimethyloxy-1,1'- [butane-1,4-diyldioxybis(nitrilomethylidyne)]dibenzene
}

\author{
Li Wang*, Jun-JiAng Wu, Yang Zhang, GANG Li and XiAng Li
}

School of Chemical and Biological Engineering, Lanzhou Jiaotong University, Lanzhou 730070, P.R. China

*Corresponding author: E-mail: wangli_78@126.com

(Received: 26 April 2012;

Accepted: 30 January 2013)

AJC-12772

\begin{abstract}
The compound 3,3'-dimethyloxy-1,1'-[butane-1,4-diyldioxybis(nitrilomethylidyne)]dibenzene with the m.f. $\mathrm{C}_{20} \mathrm{H}_{24} \mathrm{~N}_{2} \mathrm{O}_{4}$, was synthesized by the reaction of 3-methoxybenzaldehyde with 1,4-bis(aminooxy)butane in ethanol. The molecule, which lies about an inversion centre, adopts a linear structure, in which the oxime groups and benzene ring systems assume an anti conformation. The intramolecular interplanar distance between parallel benzene rings is $0.901(3) \AA$. Weak intermolecular C10-H10B $\cdots \mathrm{O} 2$ hydrogen bonds link two other molecules into infinite zig-zag supramolecular structure.
\end{abstract}

Key Words: Bisoxime compound, Synthesis, Crystal structure.

As we know, Salen-type compounds are important multidentate ligands in modern coordination chemistry ${ }^{1}$, the development of their bisoxime analogues and complexes can provide new topologies for functional materials, in which coordination forms and functionality are important variables ${ }^{2}$. And can be used to obtain non-linear optical materials ${ }^{3}$, biological systems ${ }^{4}$, interesting magnetic properties ${ }^{5}$ and building blocks for cyclic supramolecular structures ${ }^{6}$. Thus, new materials can be produced by using these compounds, which seem to be suitable candidates for further chemical modifications ${ }^{7}$. Herein, we report on the synthesis and crystal structure of 3,3'-dimethyloxy-1,1'-[butane-1,4-diyldioxybis(nitrilomethylidyne)]dibenzene.

3-Methoxybenzaldehyde was purchased from Alfa Aesar and used without further purification. 1,4-Bis(aminooxy)butane was synthesized according to an analogous method reported earlier ${ }^{8}$. The other reagents and solvents were analytical grade reagents from Tianjin Chemical Reagent Factory. $\mathrm{C}, \mathrm{H}$ and $\mathrm{N}$ analyses were carried out with a $\mathrm{GmbH}$ VariuoEL V3.00 automatic elemental analyzer. X-Ray single crystal structure was determined on a Bruker Smart 1000 CCD area detector. Melting points were measured by the use of a microscopic melting point apparatus made in Beijing Taike Instrument Limited Company and the thermometer was uncorrected.

General procedure: 3,3'-Dimethyloxy-1,1'-[butane-1,4diyldioxybis(nitrilomethylidyne)]dibenzene was synthesized according to an analogous method reported earlier ${ }^{9}$. To an ethanolic solution (10 mL) of 3-methoxybenzaldehyde (542.5 $\mathrm{mg}, 3.98 \mathrm{mmol}$ ) was added an ethanol solution $(5 \mathrm{~mL})$ of 1,4bis(aminooxy)butane $(234.5 \mathrm{mg}, 1.95 \mathrm{mmol})$. The reaction mixture was stirred at $328-333 \mathrm{~K}$ for $6 \mathrm{~h}$. The formed precipitate was separated by filtration and washed with ethanol and ethanolhexane $(1: 4)(3 \mathrm{~mL} \times 4 \mathrm{~mL})$, respectively. The product was dried under vacuum to yield $473.4 \mathrm{mg}$ of the title compound. Yield, $68.0 \%$. m.p. 335-336 K. Anal. calcd. (\%) for $\mathrm{C}_{20} \mathrm{H}_{24} \mathrm{~N}_{2} \mathrm{O}_{4}$ : C, 67.40; H, 6.79; N, 7.86. Found (\%): C, 67.72; $\mathrm{H}, 6.83 ; \mathrm{N}, 7.65$.

Colourless prismatical single crystals suitable for X-ray diffraction studies were obtained after 45 days by slow evaporation from a methanol/acetone (1:1) solution of the title compound.

X-Ray structure determination: The single crystal of the title compound, with approximate dimensions of $0.45 \mathrm{~mm}$ $\times 0.44 \mathrm{~mm} \times 0.07 \mathrm{~mm}$ was placed on a Bruker Smart 1000 diffractmeter equipped with Apex CCD area detector. The diffraction data were collected using a graphite monochromated $\mathrm{MoK}_{\alpha}$ radition $(\lambda=0.71073 \AA)$ at $298(2) \mathrm{K}$. The structure was solved by using the program SHELXS-97 and Fourier difference techniques and refined by full-matrix least-squares method on $\mathrm{F}^{2}$ using SHELXL-97. Details of the data collection and refinements of title compound are given in Table- 1 . The non-hydrogen atoms were refined anisotropically. Hydrogen atoms were added theoretically. CCDC: 877859.

$\mathrm{X}$-Ray crystallographic analysis revealed the crystal structure of the title compound. And the structure is shown in Fig. 1. 
TABLE-2

SELECTED BOND DISTANCES $(\AA)$ AND ANGLES $\left({ }^{\circ}\right)$ FOR THE TITLE COMPOUND

\begin{tabular}{cccccc}
\hline Bond & Lengths & Bond & Lengths & Bond & Lengths \\
\hline $\mathrm{N}(1)-\mathrm{C}(3)$ & $1.264(4)$ & $\mathrm{C}(1)-\mathrm{C}(2)$ & $1.510(5)$ & $\mathrm{C}(5)-\mathrm{C}(6)$ & $1.387(4)$ \\
$\mathrm{N}(1)-\mathrm{O}(1)$ & $1.410(3)$ & $\mathrm{C}(2)-\mathrm{C}(2)^{\# 1}$ & $1.518(7)$ & $\mathrm{C}(6)-\mathrm{C}(7)$ & $1.384(5)$ \\
$\mathrm{O}(1)-\mathrm{C}(1)$ & $1.424(4)$ & $\mathrm{C}(3)-\mathrm{C}(4)$ & $1.473(5)$ & $\mathrm{C}(7)-\mathrm{C}(8)$ & $1.358(5)$ \\
$\mathrm{O}(2)-\mathrm{C}(6)$ & $1.370(4)$ & $\mathrm{C}(4)-\mathrm{C}(9)$ & $1.378(5)$ & $\mathrm{C}(8)-\mathrm{C}(9)$ & $1.385(5)$ \\
$\mathrm{O}(2)-\mathrm{C}(10)$ & $1.422(4)$ & $\mathrm{C}(4)-\mathrm{C}(5)$ & $1.400(5)$ & - & - \\
\hline Bond & Angles & $\mathrm{B}(5)$ & Angles & Bond & Angles \\
\hline $\mathrm{C}(3)-\mathrm{N}(1)-\mathrm{O}(1)$ & $111.1(3)$ & $\mathrm{C}(9)-\mathrm{C}(4)-\mathrm{C}(5)$ & $120.6(4)$ & $\mathrm{C}(7)-\mathrm{C}(6)-\mathrm{C}(5)$ & $120.5(3)$ \\
$\mathrm{N}(1)-\mathrm{O}(1)-\mathrm{C}(1)$ & $108.9(3)$ & $\mathrm{C}(9)-\mathrm{C}(4)-\mathrm{C}(3)$ & $118.7(3)$ & $\mathrm{C}(8)-\mathrm{C}(7)-\mathrm{C}(6)$ & $120.2(4)$ \\
$\mathrm{C}(6)-\mathrm{O}(2)-\mathrm{C}(10)$ & $117.9(3)$ & $\mathrm{C}(5)-\mathrm{C}(4)-\mathrm{C}(3)$ & $120.7(3)$ & $\mathrm{C}(7)-\mathrm{C}(8)-\mathrm{C}(9)$ & $120.7(4)$ \\
$\mathrm{O}(1)-\mathrm{C}(1)-\mathrm{C}(2)$ & $107.3(3)$ & $\mathrm{C}(6)-\mathrm{C}(5)-\mathrm{C}(4)$ & $118.5(3)$ & $\mathrm{C}(4)-\mathrm{C}(9)-\mathrm{C}(8)$ & $119.5(4)$ \\
$\mathrm{C}(1)-\mathrm{C}(2)-\mathrm{C}(2)^{\# 1}$ & $111.6(4)$ & $\mathrm{O}(2)-\mathrm{C}(6)-\mathrm{C}(7)$ & $115.8(3)$ & - & - \\
$\mathrm{N}(1)-\mathrm{C}(3)-\mathrm{C}(4)$ & $121.9(4)$ & $\mathrm{O}(2)-\mathrm{C}(6)-\mathrm{C}(5)$ & $123.7(3)$ & - & - \\
\hline Symmetry transformations used to generate equivalent atoms: ${ }^{* 1}-\mathrm{x}+1,-\mathrm{y},-\mathrm{z}+1$. & &
\end{tabular}

TABLE-1

CRYSTAL DATA AND STRUCTURE REFINEMENT FOR THE TITLE COMPOUND

\begin{tabular}{ll}
\hline Empirical formula & $\mathrm{C}_{20} \mathrm{H}_{24} \mathrm{~N}_{2} \mathrm{O}_{4}$ \\
Formula weight & 356.41 \\
Temperature & $298(2) \mathrm{K}$ \\
Wavelength & $0.71073 \AA$ \\
Crystal system & Monoclinic \\
Space group & $\mathrm{P} 2(1) / \mathrm{c}$ \\
Cell dimensions & $\mathrm{a}=17.2666(14) \AA, \mathrm{b}=5.6832(8) \AA$, \\
& $\mathrm{c}=9.8073(7) \AA \beta=101.5540(10)^{\circ}$ \\
Volume & $942.88(17) \AA^{3}$ \\
$\mathrm{Z}$ & 2 \\
Density (calculated) & $1.255 \mathrm{mg}^{3} \mathrm{~m}^{3}$ \\
Absorption coefficient & $0.088 \mathrm{~mm}^{-1}$ \\
$\mathrm{~F}_{\text {(000) }}$ & 380 \\
Index ranges & $-19 \leq \mathrm{h} \leq 20,-6 \leq \mathrm{k} \leq 6,-10 \leq 1 \leq 11$ \\
Reflections collected/unique & $4509 / 1666\left[\mathrm{R}_{\text {(int) }}=0.0788\right]$ \\
Independent reflections & 825 \\
Data/restraints/parameters & $1666 / 0 / 120$ \\
Goodness of fit indicator & 1.052 \\
$\mathrm{R}[\mathrm{I}>2 \sigma(\mathrm{I})]$ & $\mathrm{R}_{1}=0.0422, \mathrm{wR}_{2}=0.0825$ \\
Largest diff. peak and hole & 0.0188 and $-0.0249 \mathrm{e} \AA^{-3}$ \\
\hline
\end{tabular}

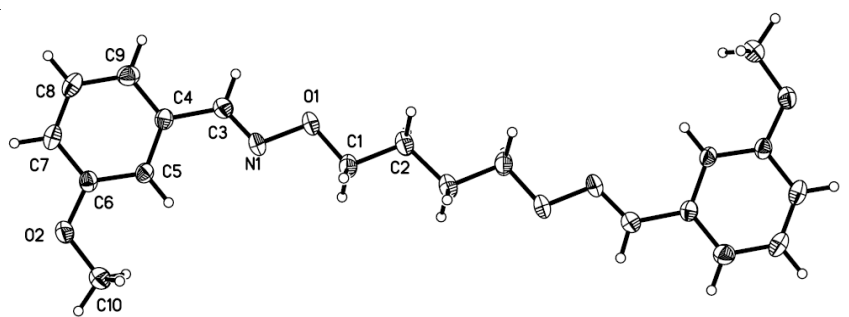

Fig. 1. Molecule structure of the title compound with atom numbering scheme. Displacement ellipsoids for non-hydrogen atoms are drawn at the $30 \%$ probability level

Selected bond distances and angles are listed in Table-2. The structure of the title compound consists of discrete $\mathrm{C}_{20} \mathrm{H}_{24} \mathrm{~N}_{2} \mathrm{O}_{4}$ molecule, in which all bond lengths and angles are in normal ranges. The molecule is disposed about a crystallographic centre of symmetry with the $\left(-\mathrm{CH}=\mathrm{N}-\mathrm{O}-\left(\mathrm{CH}_{2}\right)_{4}-\mathrm{O}-\mathrm{N}=\mathrm{CH}-\right)$ bridge, adopts a linear-shaped structure, in which the oxime groups and benzene rings assume anticonformation. This structure is not similar to previously reported Salen-type compounds containing four-methene bridge, which often adopt an E configuration $^{9,10}$.
The two benzene rings in each molecule of the title compound are parallel and the distance between them is 0.901(3) $\AA$. In the crystal structure, there are no intramolecular hydrogen bonds, four weak intermolecular hydrogen bonds, C10$\mathrm{H} 10 \mathrm{~B} \cdots \mathrm{O} 2(\mathrm{~d}(\mathrm{C} 10-\mathrm{H} 10 \mathrm{~B})=0.96 \AA, \mathrm{d}(\mathrm{H} 10 \mathrm{~B} \cdot \mathrm{O} 2)=2.65 \AA$, $\left.\mathrm{d}(\mathrm{C} 10 \cdots \mathrm{O} 2)=3.461(3) \AA, \angle \mathrm{C} 10-\mathrm{H} 10 \mathrm{~B} \cdots \mathrm{O} 2=129^{\circ}\right)$, link two other molecules into infinite zig-zag supramolecular structure (Fig. 2) $)^{11-14}$.

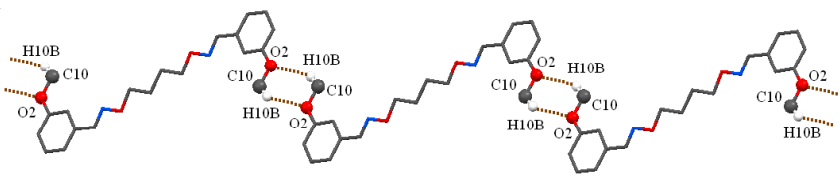

Fig. 2. Part of zig-zag supramolecular structure of the title compound. Intermolecular hydrogen bonds are shown as dashed lines

\section{ACKNOWLEDGEMENTS}

The authors acknowledged the financial support from 'Jing Lan' Talent Engineering Funds of Lanzhou Jiaotong University.

\section{REFERENCES}

1. S. Akine, T. Taniguchi and T. Nabeshima, Angew. Chem. Int. Ed., 41, 4670 (2002).

2. W.K. Dong, G. Wang, S.S. Gong, J.F. Tong, Y.X. Sun and X.H. Gao, Transition Met. Chem., 37, 271 (2012).

3. H. Miyasaka, N. Matsumoto, H. Okawa, N. Re, E. Gallo and C. Floriani, J. Am. Chem. Soc., 118, 981 (1996).

4. P.G. Lacroix, Eur. J. Inorg. Chem., 339 (2001).

5. T.K. Ronson, H. Adams and M.D. Ward, Inorg. Chim. Acta, 358, 1943 (2005).

6. A.K. Sharma, F. Lloret and R. Mukherjee, Inorg. Chem., 46, 5128 (2007).

7. C. Policar, F. Lambert, M. Cesario and I. Morgenstern-Badarau, Eur. J. Inorg. Chem., 12, 2201 (1999).

8. D.A. Atwood and M.J. Harvey, Chem. Rev., 101, 37 (2001).

9. W.K. Dong, X.N. He, C.M. Dong, L. Wang, J.K. Zhong, X. Chen and T.Z. Yu, Z. Kristallogr. New Cryst. Struct., 222, 289 (2007).

10. W.K. Dong, X.N. He, Y.X. Sun, L. Xu and Y.H. Guan, Acta Cryst., E64, o1917 (2008).

11. W.K. Dong, X.N. He, H.B. Yan, Z.W. Lv, X. Chen, C.Y. Zhao and X.L. Tang, Polyhedron, 28, 1419 (2009).

12. H.L. Wu, X.C. Huang, J.K. Yuan, F. Kou, F. Jia, B. Liu and Y. Bai, Z. Naturforsch., 66b, 1049 (2011).

13. W.K. Dong, Y.X. Sun, Y.P. Zhang, L. Li, X.N. He and X.L. Tang, Inorg. Chim. Acta, 362, 117 (2009).

14. W.K. Dong, J.G. Duan, Y.H. Guan, J.Y. Shi and C.Y. Zhao, Inorg. Chim. Acta, 362, 1129 (2009). 